\title{
Economic crisis, Henryk Grossman and the responsibility of socialists
}

\section{Rick Kuhn}

\author{
Isaac and Tamara Deutscher Memorial Lecture \\ 7 November 2008 \\ School of Oriental and African Studies, London
}

\begin{abstract}
Henryk Grossman's discussion of economic crises was designed to complement his Leninist understanding of politics. For Grossman, as for Marx, the fundamental contradiction of capitalist production is between the unlimited scope for expanding the output of use values and restrictions imposed by the framework of producing profits. The increasing weight of capitalists' outlays on dead compared to living labour, which is the only source of new value, gives rise to the system's tendency to break down and hence to economic crises. Deep financial crises can only be understood in the context of developments in production and particularly movements in the rate of profit. The initial widespread hostility to Grossman's development of Marxist economics can mainly be explained in terms of the logics of social democratic and Stalinist politics. In contrast to dominant views on the left today, the Marxist tradition in which Grossman stood places the construction of organisations capable of assisting the working class's conquest of political power at the heart of the responsibility of socialists. Grossman's political practice expressed his understanding of the close relationship between capitalism's breakdown tendency and the importance of building a revolutionary party.
\end{abstract}

\section{Keywords}

breakdown tendency, capital accumulation, capitalist crisis, crisis, communism, economic crisis, Edward Said, Henryk Grossman, Henryk Grossmann, Jewish Social Democratic Party, Karl Marx, Marxism, Noam Chomsky, rate of profit, revolutionary party, socialism, Vladimir Ilyich Lenin, working class, 



\section{Economic crisis and the responsibility of socialists}

Henryk Grossman is particularly relevant today and not only because of his explanation of economic and financial crises, which I will briefly recapitulate. That theory was formulated and can only be understood as an element in a broader, classically Marxist analysis of capitalist society and the way it can be superseded. The specifics of Grossman's political outlook help explain the generally hostile reception of his work in the immediate wake of the publication of his best-known study, The law of accumulation and breakdown of the capitalist system, being also a theory of crises, and subsequently. Grossman expressed his revolutionary Marxism not only in his writings but also in political activity. That was not always flawless, on the contrary. But his views about the responsibilities of socialists are superior to fashionable notions of the responsibilities of intellectuals. Furthermore, the continuities and discontinuities in his practice and, in some periods, the inconsistencies between it and his theoretical commitments are instructive.

\section{Economic crisis}

The purpose of Henryk Grossman's economic researches was to advance the class struggle. From 1920, if not before, he subscribed to a particular, Leninist conception of Marxist politics which overlapped with views he had already put into practice well before the First World War, particularly by helping to build a revolutionary organisation of Jewish workers in Galicia.

If Lenin recovered Marx's revolutionary conception of politics, Grossman recovered the revolutionary content and implications of Marx's economic analysis. Like Lukács, who also drew on Lenin and restored contradictory class interests and perspectives to the centre of Marxist philosophy, he stressed capitalism's crisis-prone logic and its mystification of that logic. By exploring the economic roots and implications of commodity fetishism and their relationship to capitalist crises and revolution Grossman therefore also complemented Lukács's arguments in History and class consciousness, which focused on ideology and revolution but not economics. ${ }^{1}$

Marxist and other criticisms of the way capitalism generates oppression and alienation powerfully justify the struggle for socialism. As a young man, Grossman was himself actively involved the Jewish working class's fight against both oppression and exploitation. But, following Rosa Luxemburg and against those who thought that capitalism could be reformed into socialism, he insisted that Marx regarded the bourgeoisie as incapable of consistently sustaining workers' lives. ${ }^{2}$ Capitalism has a tendency to break down economically, throwing a part of the working class out of work and attacking the living standards of those who retain their jobs. Today that tendency is particularly apparent.

Grossman made two major contributions to our understanding of economic crises. The first was already outlined in 1919, developed in his 1929 The law of accumulation and further elaborated in (semi-published) detail in $1941 .^{3}$ Capitalist production, he pointed out following Marx, is at once a labour process creating use values with particular physical characteristics and a process of selfexpanding value creating new wealth through the exploitation of wage labour. This analysis provided

\section{Notes}

1 Lukács 1971, pp. 83-84.

2 Marx and Engels 1970, pp. 38, 41, 44.

3 Grossman 2000, pp. 171-80; Grossmann 1977. 
a means of eliminating what was deceptive in the pure categories of exchange-value, thus creating a foundation for further research into capitalist production and affording him the possibility of grasping the real interconnections of this mode of production behind the veil created by value. ${ }^{4}$

The satisfaction of the requirements for the proportional expansion of both these processes at once can only be passing and accidental. Far from being characterised by equilibrium - as assumed by the inaccurate and static assumptions of mainstream economics - capitalism is necessarily dynamic, uneven and crisis prone. Grossman demonstrated that this was even true in the case of simple reproduction, where the scale of output does not expand. ${ }^{5}$

Furthermore, capitalism's tendency to break down is grounded in a contradiction at the heart of the production process. There is unlimited technical scope to expand the productivity of human labour, but this is restricted by the logic of production for profit, giving rise to the breakdown tendency. ${ }^{6}$ The exposition and defence of Marx's account of the way capitalism limits the possibilities for the self-expansion of value was Grossman's second, and best known, contribution to crisis theory. It is, however, grounded in the first.

Capital accumulation means that the proportion between the numbers of specific kinds of means of production (raw materials, buildings, machinery etc) used in production increases compared to the number of workers employed. This is the technical composition of capital. The ratio of the values of means of production to means of consumption (on which workers spend their wages) - the value composition of capital - changes as, with technological advances, the amount of labour time (the foundation of value) required to make them declines unevenly. In the longer term, however, there is no reason to believe that the value of means of production falls more rapidly than the value of means of consumption. So the organic composition of capital, which expresses the effects of the technical composition of capital on the value composition of capital, tends to rise: capitalists spend increasingly more on means of production than on buying labour power. As Grossman pointed out in a passage that does not appear in the English translation of The law of accumulation

The pure value perspective that has been taken over from bourgeois economics has already permeated so deeply into the consciousness of Marx's epigones of all colours, from reformists to communists, that the most basic Marxist concepts have been distorted and corrupted. Thus the concept of the organic composition of capital. Marx distinguishes a technical and a value composition and finally, as the third concept, the organic composition, by which designation he understood the 'reciprocal relationship' of the two previously identified, namely 'the value composition of capital, in so far as it is determined by its technical composition and reflects changes in it'. The organic composition of capital, formulated in this way 'is the most important factor' in inquiry into capital accumulation. Of all this not a trace remains in the work of Marx's epigones. $^{7}$

Amongst the mistaken commentators on the organic composition of capital, Grossman counted the social democrats Karl Kautsky, Rudolf Hilferding and Emil Lederer; the Communists Eugen/Jenö Varga and Nelli Auerbach; and the academic Ladislaus von Bortkiewicz, who ostensibly solved the 'transformation problem'. The organic composition of capital is important because it is only living labour that gives rise to new value. If organic composition rises while the rate of exploitation, the

4 Grossmann 1977, p. 39.

5 Grossmann 1977, pp. 41, 81-85.

6 Grossmann 1970, pp. 619-20.

7 Grossmann 1970, pp. 326-327. 
amount of surplus value produced will remain the same but capitalists will have spent more to generate it. The rate of profit will have fallen.

Marx and Grossman identified the tendency for the rate of profit to fall as a crucial contradiction in the process of self-expanding value. They also described mechanisms which serve to counter-act it. Amongst the countertendencies is the intrinsic cheapening of means of consumption through technological change, which can lead to increases in the rate of exploitation without cuts in workers' living standards. Crises also eventually lead to improvements in profitability as bankrupt or failing businesses sell off their assets at a discount to other firms whose costs of production are thus reduced. Furthermore, when means of production lie idle and decay crises destroy value. War has similar consequences. But there are other measures which capitalists and states can deliberately pursue to maintain or improve profit rates. Amongst these, attacks on workers' living standards are particularly significant. Grossman explained that capitalism's breakdown tendency takes the form of recurrent economic crises, conditioned by the empirical course of the tendency for the rate of profit to fall and its countertendencies. For him, the tendency for capitalism to break down was definitely not a unidirectional path to final collapse.

There is also a fundamental connection between capitalism's crisis tendency and imperialism. Before World War I, Marxists had elaborated theories of imperialism as a necessary consequence of capitalist development. Karl Kautsky linked this with capitalism's crisis tendency, which he generally understood in underconsumptionist terms, the problems capitalists have in realising the surplus value embodied in commodities by selling them.

The system of trusts and cartels and that of militarism cannot guarantee the capitalist mode of production against collapse. Neither can the export of capital with its resulting new-type colonial system. However, the new colonial system, like the system of trusts and cartels and that of militarism, has become a mighty means of holding back this collapse for several decades.

Colonial policy has become a necessity for the capitalist class, just as militarism has. ${ }^{8}$

Kautsky changed his mind in 1914. Like the starry-eyed proponents of globalisation as the guarantor of world peace up to (and even beyond) the US-led invasions of Afghanistan and Iraq, Kautsky now maintained that the degree of integration of capital across national boundaries, 'ultraimperialism', reduced the likelihood of war.

Rudolf Hilferding asserted, in 1910, that imperialism was 'the economic policy of finance capital', 'bound to lead towards war.' He insisted that 'the idea of a purely economic collapse makes no sense' and did not link imperialism to capitalism's crisis tendencies. ${ }^{9}$ Rosa Luxemburg, however, provided an explanation of imperialist expansion into non-capitalist territories as a means to offset capitalism's inability to realise the surplus value it had created.

Accumulation is impossible in an exclusively capitalist environment. Therefore, we find that capital has been driven since its very inception to expand into non-capitalist strata and nations, ruin artisans and peasantry, proletarianise the intermediate strata, the politics of colonialism, the politics of 'opening-up' and the export of capital. ${ }^{10}$

Otto Bauer demonstrated that Luxemburg's proof that capitalism's survival depended on its expansion into non-capitalist territories or spheres of production was wrong. He used a version of

8 Kautsky 2002, chapter 6; also see Kautsky 1902, pp. 37-47, 76-81, 110-118.

9 Hilferding 1981, p. 366.

10 Luxemburg 1972, p. 145; also see Luxemburg 1963, pp. 366-367. 
Marx's reproduction schemes, tables that followed the pattern of accumulation over successive years given certain assumptions, to show that capitalism could survive in a purely capitalist world. ${ }^{11}$

Amongst the leading Bolsheviks, while Nikolai Bukharin did not identify capitalism's tendency to breakdown as a cause of imperialism in his major study, ${ }^{12}$ Lenin did. But he wrote little more than 'The need to export capital arises from the fact that in a few countries capitalism has become "overripe" and (owing to the backward state of agriculture and the poverty of the masses) capital cannot find a field for "profitable" investment."

Paradoxically, Bauer's refutation of Luxemburg was the starting point for Grossman's vindication of her basic positions: that a breakdown tendency is inherent in capitalism and gives rise to imperialism. Grossman extended a simplified version of Bauer's own reproduction scheme beyond a few years and found that the system broke down because of the tendency for the rate of profit to fall. He specified the nexus between capital accumulation, crisis, imperialism and war in terms of efforts by capitalists and states to offset the fall in the rate of profit. In particular, unequal exchange, through foreign trade, helps bolster the profits of imperialist powers at the expense of less developed countries, ${ }^{14}$ while monopoly control over raw materials does so to the cost of their imperialist rivals. ${ }^{15}$

\section{Finance capital and neo-harmonism}

As during the 1920s and 1930s, orthodox economists and governments have attributed the economic crisis that began in 2007 to a lack of effective state regulation and/or transparency of the financial system. ${ }^{16}$ Identifying the immediate causes of the current crisis is an empirical task. Problems in the realm of finance and inadequate state regulation have, indeed, been a trigger. But there is also a methodological question: are there underlying, more fundamental processes that ultimately condition or give rise to the surface appearance of the crisis. The issue here is that of abstraction. Henryk Grossman already stressed the importance of going beyond 'naïve empiricism' by abstracting from less salient features of the real world in order to lay bare underlying structures in a 1919 lecture. In The law of accumulation, he explicitly drew attention to, and himself employed, Marx's method in Capital, by initially abstracting from and then successively reintroducing the complicating factors that are characteristic of concrete reality. As Grossman pointed out in a supplementary essay, Marx reorganised his plan for Capital precisely in order to implement this method in his explanation of the capitalist mode of production. ${ }^{17}$

The growth of financial speculation over recent decades was spectacular. 'Sub-prime' housing loans in the USA were only one aspect of the phenomenon. Foreign exchange transactions in 2004 were more than sixty times greater than the value of all the world's exports. In 2005, the notional amount of over-the-counter foreign exchange derivatives was almost two and a half times greater than the value of global exports. ${ }^{18}$ Other indices of the flow of capital into speculative rather than productive

11 Bauer 1986, pp. 88-110.

12 Bukharin 1973; also see Bukharin 1972.

13 Hilferding 1981; Bukharin 1973; Lenin 1977, p. 679.

14 Grossmann 1970, pp. 434, 437-438; Grossmann 1992, p. 172

15 Grossmann 1970, pp. 450-454, 466-467; Grossmann 1992, pp. 174-176.

16 See, for example Paul Krugman (later in 2008, winner of the Nobel Prize in Economics) 2008; Mandel 2008; Davidson 2008, p. 15; Associated Press 2008.

17 Grossmann 1929, pp. 305-338. A section of the article is translated into English in Lapides 1992.

18 For the relationship between foreign exchange transactions and the value of exports see World Trade Organization, 2005, 1; Bank for International Settlements 2005. For derivatives and exports see International Monetary Fund 2007, Statistical appendix tables 3 and 4; and World Trade Organization 2006, pp. 3, 195-198, 203-205. Both 
investment were the scale of private equity/leveraged buyouts and the fact that hedge funds in 2006 managed over US\$1.1 trillion. While the US finance sector only realised 10 per cent of total corporate profits in 1980, the figure was 40 per cent in $2007 .{ }^{19}$ Most of the transactions on financial markets are a zero sum game: players only gain at each others' expense. The key question is why this shift, which some have called 'financialisation', has taken place.

Grossman pointed out in 1929 that, as the rate of profit declines capitalists in productive sectors will increasingly turn to speculative activity. ${ }^{20}$ This goes a long way towards explaining recent developments. Low profit rates characterised the end of the long boom of the 1950s and the 1960s. They recovered in the wake of the recessions of the mid 1970s, early 1980s and early 1990s - each in turn the deepest since the Depression. But not to the levels of the long boom. So capitalists invested at an increasing rate in speculative financial assets rather than productive activity. ${ }^{21}$ Grossman insisted

the very laws of capitalist accumulation impart to accumulation a cyclical form and this cyclical movement impinges on the sphere of circulation (money market and stock exchange). The former is the independent variable, the latter the dependent variable. ${ }^{22}$

On this basis, he attacked social democratic 'neo-harmonists' like Rudolf Hilferding, twice Germany's Finance Minister during the 1920s, who argued that it was possible for the working class to take state power by parliamentary means and to overcome capitalism's pattern of booms and slumps on the road to socialism. The growing domination of production by larger and larger corporations and cartels, Hilferding maintained, meant that a government could achieve a forthright program of reform by managing the capitalist economy, especially through state control over the banking system.$^{23}$ Resistance from the German Social Democrats' coalition partners and the Party's own timidity meant that he never put his ideas into practice. But governments whose pronouncements were ever-so-recently neo-liberal are now trying out Hilferding's prescriptions for pragmatic reasons. This applies in Europe, Asia and North America, but I will provide an antipodean example.

In 2007 before the elections that made him Australia's Prime Minister, Kevin Rudd reassured business that he was 'a fiscal conservative'. But in early October 2008, the Labor Government decided valour was the better part of discretion by speeding up expenditure on public infrastructure from the Future Fund. Again, this was designed to reassure corporate Australia: Labor will do whatever it takes to secure growth and, especially, profits. In the face of the crisis, a prolonged and careful assessment of how to spend the billions of dollars in the Fund on competing projects was set aside. It was necessary to get the money flowing to make up for the very rapid anticipated slowdowns in Australian investment, consumption and income from the export of minerals to China. A few days later the Board of the Reserve Bank of Australia, on which the head of Treasury sits alongside a majority of corporate heavy-weights, had the same fears as the Government. So it cut the official interest rate by a whole one percent, for the first time since $1992 .{ }^{24}$ Further, larger and more desperate reductions in interest rates and attempts to boost demand followed.

comparisons are understated because large volumes of exports within the European Monetary Union are denominated in Euros and do not require foreign exchange transactions.

The economist 2006; The economist 2008.

Grossmann 1992, pp. 191-193.

Harman 2008, pp. 27-42. For a survey of data on profit rates see Harman 2007, pp. 141-161. 
These measures looked like Keynesian economics, where the government steps in to sustain growth and make up for the deficiencies of markets. But the massive policy shift was more than Keynesian. Governments of the world's most prosperous countries provided tens and hundreds of billions of pounds and dollars to bail out first private and state banks and then strategic manufacturing corporations. In the USA, Britain, Belgium, Luxembourg, the Netherlands and Iceland, they nationalised failing banks. Some Republicans in the United States and conservatives elsewhere expressed concerns about creeping 'socialism', as governments made gifts to and took over banks and promised to regulate the rest much more closely. ${ }^{25}$ As the crisis deepens, there is bound to be even more overt state involvement in economic activity and more of this kind of 'socialism', of which Hilferding would have approved. Yet, whether such state capitalist measures are deemed 'socialist' or not, the important final chapter of The law of accumulation (missing from the English translation) concluded that they are unlikely to resolve the underlying problems. ${ }^{26}$

As the crisis in the real economy intensifies, capitalists and governments are turning, pragmatically, to measures that will help to restore profit rates. This is also true of big spending governments, some of which invoke Keynes. 'In the national interest' they call on everyone to 'tighten their belts' for the common good. They have 'wage restraint' and 'responsible management' of social security outlays in mind. In other words, they will intensify the class struggle from above, attempting to raise profit rates by increasing the rate of exploitation. Inflation and currency devaluations can have this effect too, as Grossman pointed out in relation to the French Socialist premier Léon Blum's devaluation of the franc in September 1936. ${ }^{27}$ In the short term, as unemployment rises, such measures will intensify the economic contraction by reducing consumer demand. In the longer run, at the expense of mass misery, successful attacks on workers will help overcome the crisis. Another vital factor in a recovery is the devalorisation of capital resulting from bankruptcies, the sale of failing businesses in the productive sector at large discounts, and state imposed rationalisation of industries by shutting down less efficient operations.

Grossman drew conclusions, which reflected his political orientation, from his analysis.

If capital now succeeds in pressing down wages and thus raising the rate of surplus value... the existence of the capitalist system can be prolonged at the expense of the working class, the intensification of the breakdown tendency slowed down and thus the end of the system postponed to the distant future... Conversely, if working class resistance counteracts or overwhelms pressure from the capitalist class, the working class's struggles can win wage rises. Thus the rate of surplus value will decline and consequently the breakdown of the system will accelerate... It is thus apparent that the idea of a breakdown that is necessary on objective grounds, definitely does not contradict the class struggle. Rather, the breakdown, despite its objectively given necessity, can be influenced by the living forces of the struggling classes to a large extent and leaves a certain scope for active class intervention. ${ }^{28}$

\section{Reception}

Grossman's book quickly became a reference point in Marxist economics. But, with a few exceptions, reviewers and commentators were very hostile. The main reasons are straightforward. In The law of accumulation, Grossman had attacked a series of prominent socialist economists in less than restrained terms. Many responded in kind. More importantly, his analysis was

Skapinker 2008; White 2008.

Grossmann 1970, pp. 610-19. 
incompatible not only with bourgeois and social democratic but also Stalinist and council communist politics. ${ }^{29}$

The reassertion of Marx's argument that a tendency to break down was inherent in capitalism found no sympathy amongst defenders of the existing order and advocates, even ostensibly Marxist ones, of reforming capitalism into socialism. Grossman's book appeared in the course of the Stalinist counter-revolution in Russia. The construction of a police state, competing militarily with western imperialism through rapid capital accumulation based on the hyper-exploitation of the working class and peasantry, had consequences in the realm of ideas. Stalin's regime was imposing unchallengeable orthodoxies on the discussion in the Communist movement of many areas of life, ranging from literature and music, though history, social analysis and policy, to military doctrine and biology. Stalin anointed Jenö Varga as the guardian of Communist economic dogma in $1930 .{ }^{30}$ Varga, whom Grossman had specifically labelled an 'epigone of Marx', ${ }^{31}$ subscribed to an underconsumptionist explanation of economic crises which drew, unacknowledged, on Luxemburg. Grossman's approach, which - following Marx - stressed that the fundamental contradictions of capitalism derived from the organisation of production rather than the circulation of value, was therefore heresy. A focus on the production relations, at the heart of the logic of capitalism, might also prove embarrassing if applied to the way work was organised in the Soviet Union.

The two main currents in the labour movement therefore agreed that Grossman's analysis was flawed and mechanical, a theory of the automatic collapse of capitalism. Most council communists concurred. They did not distinguish between Lenin's development of the theory and practice of working class self-emancipation, that Grossman's economic analysis was designed to complement, and Stalinism.

Where and when Grossman's work was taken seriously on the left, it was on the margins of the workers' movement. In particular Paul Mattick, a council communist, was a consistent proponent of Grossman's approach to Marxist economics from 1931 until the 1980s. The two corresponded until Grossman moved to the United States, where they had contact with each other at least until the early 1940s. Mattick rejected critiques of Grossman, formulated by two of the most prominent figures in his own political current, Anton Pannekoek and Karl Korsch. He shared their rejection of Leninist politics but simply sheared off this, for Grossman, crucial aspect of his analysis, defending only Grossman's main economic arguments. On the basis of two reviews, Antonio Gramsci in prison expressed interest in Grossman's approach to economic crises. ${ }^{32}$

Later, Bernice Shoul, associated with the Socialist Workers Party in the United States during the 1940s, drew on Grossman's work in writings between 1947 and $1967 .{ }^{33}$ So did her friend Jean van Heijenoort, formerly one of Trotsky's secretaries, in a single article published in Paris, shortly before he broke with Marxism. ${ }^{34}$ The veteran Trotskyist historian Roman Rosdolsky in 1957 expressed reservations about Grossman's analysis but defended Marx and Grossman against Martin Trottmann's recycled, academic criticism of any theory of breakdown in general and Grossman's reproduction scheme in particular.

29 For the immediate reception of The law of accumulation, see Kuhn 2007, pp. 141-148, 265-266; on Grossman's responses see Kuhn 2004, pp. 181-221.

30 Day 1981.

31 Grossmann 1970, p. 517.

32 Antonio Gramsci 1995, p. 430; and, not in the English translation, Gramsci 2008, p. 184.

33 Shoul 1947; 1957, 1965 and 1967.

34 Alex Barbon (Jean van Heijenoort) 1946. 
It was not until the late 1960s, with the growth of the radical student movement in Germany, that Grossman's work and Marx's theory of capitalist breakdown found a new, wider and more receptive audience. Two leftwing publishing houses, one of them created by members of the radical Sozialistischer Deutscher Studentenbund, republished Grossman's main economic works between 1967 and 1971. ${ }^{35}$ Paul Mattick continued to promote Grossman's economic theory to English and German speaking audiences and beyond. There were translations of Grossman's work into other languages. Capital and class carried his essay 'Marx, classical political economy and the problem of dynamics' in 1977. Jairus Banaji's abridged translation of The law of accumulation was published in 1992. Several substantial essays by Grossman, however, are yet appear in English.

From the early 1970s, there was a flurry of interest in Grossman's analysis of economic crises in German and English. ${ }^{36}$ This continued into the early 1980s, but subsequently slowed down, as class struggles and the Marxist left declined, especially in the universities. Most of the references to Grossman focussed on economic theory. There are, however, recent, more empirical applications of Marx's approach along the lines of Grossman's analysis by, for example, Chris Harman and Patrick Bond. ${ }^{37}$ But the dominant view, shared by a spectrum that has stretched from Stalinist textbooks in East Germany through various anti-stalinist Marxist economists to the most influential account of the history of Marxist economics, by two radical economists, has been that Grossman's approach is flawed..$^{38}$ The impressively scholarly biography of Grossman by Jürgen Scheele, reproduced such assessments..$^{39}$ Since the 1970s, many critiques of Grossman and/or Marx's presentation of the tendency for the rate of profit to fall by both non-Marxist radicals and self-identified Marxists, have invoked the 'Okishio Theorem', which relies on an equilibrium methodology alien to Marxism. After the revival of Marxism associated with the mass struggles of the 1960s and 1970s subsided, bourgeois economics again increasingly 'permeated' the consciousness of the briefly expanded ranks of 'Marx's epigones'. ${ }^{40}$ Alan Freeman has aptly labelled such attempts to explain Marxist economics using tools and assumptions drawn from neo-classical economic theory 'Walrasian Marxism' ${ }^{41}$

Most of the treatments of Grossman's economic theories since the 1960s have been undertaken in ignorance of his political orientations. The logic of his theory of breakdown is still self-evidently anathema to those committed to a reformist path to socialism, let alone proponents of a stable and humane capitalism.

\section{The responsibility of socialists}

Grossman stated, in an implicit but hardly disguised reference to Vladimir Ilych Lenin, that his treatment of capitalism's tendency to break down was intended to complement analyses of the politics of revolution. ${ }^{42}$ His account was designed to help revolutionaries identify the objective

35 Körner 1996; Verlag Neue Kritik n. d.

36 See, for example Schmiede 1973; Deutschmann 1973; David Yaffe 1973.

37 Harman 2007 and 2008; Bond 1998; also see ten Brink and Walter 2001.

38 Stalinist textbooks: Behrens 1952, pp. 45-48; Behrens 1976, pp. 232-236; Krause and Rudolph 1980, p. 321, simply invoke Behrens's 1976 pronouncements. Behrens had been instrumental in bringing Grossman to Leipzig in 1949. Howard and King 1989 pp. 316-336

39 Scheele 1999. Also see the rejection of breakdown theory and a positive assessment, drawing on interpretations, developed in East Germany and by the (West) German Communist Party's research institute, of the possibilities for 'democratic and social progress' under contemporary capitalism, in Finthammer et al. 1989.

40 Howard and King 1992 pp. 138, 144-145, 316-317; Heinrich 2006, pp. 337-340.

41 See Freeman 1996; Kliman 2007, pp. 46-53; Freeman 2008, pp. 122-131.

42 Grossmann 1992, p. 33. 
circumstances in which intense class struggles and revolution were likely to emerge. When discussing the politics of insurrection, he explicitly referred to Lenin as an expert. ${ }^{43}$ From both his writings and his political practice, Grossman's Leninist conception of revolutionary politics (the need to smash the capitalist state) and organisation (the role of a revolutionary party) are clear, except to those wedded to social democracy, Stalinism or their academic legacies.

Yet Henryk Grossman's practical political activities expressed his conception of the responsibilities of socialists more eloquently than his writings. In pursuit of the goal of working class selfemancipation, Grossman's actions resisted the dominant currents of Polish and Jewish nationalism, social democracy and, for a brief period, Stalinism. At the centre of his approach to politics was a commitment to building a revolutionary party.

The view that those critical of the established order should be involved in organisations devoted to bringing that order down is currently unpopular. The expectation that intellectuals, scientists and academics should be dispassionate, 'objective' and apolitical is as widespread as the positivist conception of science. Even amongst those who publicly take sides, it is scandalously common for radicals in words to be rather politically inactive in their deeds. Moreover, most of those who engage in struggles against exploitation or oppression do not do so through involvement in organisations 'dedicated not to building freedom but to moving the working class to build it', ${ }^{44}$ which attempt to tie struggles for reforms to the project of revolutionary change. Beyond the pragmatic assertion that 'the time is not ripe' for any practical activity, there are arguments that people, intellectuals in particular, should avoid making commitments to revolutionary organisations. It is worth considering the most influential of these before examining the case made by Grossman's practice.

\section{Liberal, reformist and radical conceptions of responsibility}

Julien Benda would have regarded Grossman as a co-accused in the 'betrayal of the intellectuals'. In 1927 Benda formulated a metaphysically rationalist conception of intellectuals and denounced their 'betrayal' by participating in mass political passions. Instead they should devote themselves to the truth, "every life which pursues only spiritual advantage or sincerely asserts itself in the universal, situates itself outside the real' 'and hence in a certain manner say: "My kingdom is not of this world"'. Benda was, however, a defender of Dreyfus and an anti-fascist, who believed that intellectuals should proclaim the truth even when this did not find favour with the authorities. ${ }^{45}$

In his Representations of the intellectual, Edward Said appropriated the core of Benda's argument: intellectuals are an elite of special 'individuals with a vocation for the art of representing' positions 'to, as well as for, the public', who should be devoted to proclaiming the truth and consequently 'always [stand] between loneliness and alignment'.

[T] here is a special duty to address the constituted and authorized powers of one's own society, which are accountable to its citizenry, particularly when those powers are exercised in a manifestly disproportionate and immoral war, or in a deliberate program of discrimination, repression, and collective cruelty.

More consistently than Benda, Said stressed 'the importance to the intellectual of passionate engagement, risk, exposure, commitment to principles, vulnerability in debating and being involved in worldly causes'; and 'that the intellectuals belong on the same side with the weak and unrepresented' ${ }^{46}$ Said's own professional and political work impressively matched his conception

\footnotetext{
43 Grossmann 1928, pp. 161-62.

44 MacIntyre 2008b, p. 132.

45 Benda 1959, pp. 25, 30.

46 Said 1994, pp. 10-13, 22, 98, 109.
} 
of the role of an intellectual. He exposed the pervasiveness of imperialist modes of thought, particularly in high culture, and supported the struggles of his fellow Palestinians even when these were undermined by the leadership of the Palestinian Liberation Organisation.

Although, for Said, political passions were acceptable, even desirable, a residue of Benda's emphasis on intellectual disinterestedness remained in his warning against political 'gods that always fail' and 'joining up, not simply in alignment but in service and, though one hates to use the word, collaboration'. Said presented a false choice. On the one hand, he told us about McCarthyism, apostates who flipped over from Stalinism or Trotskyism to the right, and the need to avoid 'subservience to authority'. On the other hand, he portrayed true intellectuals with their convictions derived from their work and 'a sense of association with others', but 'not acting at the behest of a system or method', and essentially alone. While cautioning against system and method, Said snuck their ghostly moral shades through the wall, by invoking 'a consistent and universalistic ethic' ${ }^{47}$ His is a conventional, individualistic, liberal morality. It excludes the possibility that, to be effective in the struggle for human freedom, our critical abilities may best be exercised collectively. ${ }^{48}$

Said's book began as the 1993 Reith Lectures for the BBC. He was an astute choice for this honour: a controversial figure in literary studies and on the Palestinian question who could attract an audience, yet his argument did not go far beyond the bounds of liberal protest at oppression. It struck a chord in a period when the extent of mass struggles was limited and the anti-capitalist left, particularly the organised anti-capitalist left was shrinking. It appealed to those who identified with the suffering of the oppressed but did not challenge the individualism of bourgeois common sense or the self-regard of intellectuals, confident about their own special social role. And it was summed up in a catchy slogan. 'Speak truth to power' ${ }^{49}$ is vastly more respectable than an injunction to promote mass action to change the world, however neatly or succinctly expressed.

The phrase was first published in a US Quaker pamphlet. ${ }^{50}$ Its roots are in the Quaker tradition of bearing witness on matters of social conscience and, further back, in narrowly theological propositions in the New Testament passages about Jesus's divine status and the related formulation that 'the truth shall make you free' ${ }^{51}$ It can embody an approach to change, through dialogue with those in authority, that is no threat to the established order. Teresa Kerry used it at the 2004 Democratic Party Convention in a speech supporting her husband's campaign for the US presidency. ${ }^{52}$ But invoking Said's call to 'speak truth to power' is a lot cooler and seems more radical than acknowledging the slogan's Quaker roots. ${ }^{53}$ It also achieves little: as Lukács pointed out, the capitalist class's position in society makes it incapable of recognising some fundamental truths. $^{54}$

Noam Chomsky, succinctly specified the nature of power and the relationship of intellectuals, as a social layer with specific material interests, to it: 'They are, in Gramsci's phrase, "experts in

47 Said 1994, pp. 110-113, 119-121. For a systematic critique of Said's approach see Ahmad 1994, especially pp. $169-170$.

48 For discussions of Marxist approaches to ethics see MacIntyre 2008, pp. 45-68, 123-134; Blackledge 2008.

49 Said 1994, pp. xvi, 6, 8, 88, 97, 102.

50 American Friends Service Committee 1955.

51 Bible, John 8.18 and 8.32 .

52 New York Times 2004.

53 Hence the T shirt, available in a myriad of size, colour and style permutations, with a portrait of Said on the front and 'speak truth to power' on the back, http://www.zazzle.com/edward_said_shirt-235059530572725686, accessed 24 June 2008. Calavita 2002, p. 14.

54 Lukács 1971, pp. 46-81. 
legitimation." They must ensure that beliefs are properly inculcated, beliefs that serve the interests of those with objective power, based ultimately on control of capital in the state capitalist societies. ${ }^{55}$ Chomsky has demolished the moralistic, liberal approach to politics and the notion that intellectuals need their own special code of behaviour.

... my Quaker friends and colleagues in disrupting illegitimate authority adopt the slogan: "Speak truth to power." I strongly disagree. The audience is entirely wrong, and the effort hardly more than a form of self-indulgence. It is a waste of time and a pointless pursuit to speak truth to Henryk Kissinger, or the CEO of General Motors, or others who exercise power in coercive institutions - truths that they already know well enough, for the most part.'

To speak truth to power is not a particularly honourable vocation. ${ }^{56}$

If you want to change the way things are then 'the intellectual responsibility of the writer, or any decent person, is to tell the truth.' More specifically 'The responsibility of the writer as a moral agent is to try to bring the truth about matters of human significance to an audience that can do something about them. ${ }^{57}$ This link between telling the truth and political action was also a central argument in Chomsky's famous essay 'The responsibility of intellectuals'. ${ }^{58}$

Yet Chomsky has become more coy about 'the truth' recently. 'We don't know the truth. At least I don't', he has asserted. ${ }^{59}$ This claim is disingenuous, or at least self-contradictory. Clearly in making all the generally excellent arguments he does in books, articles and interviews about a range of issues, especially US foreign policy, Chomsky thinks he knows better than mainstream politicians and the mass media. And he is right. He usually does know much better, if not the final, absolute 'truth'. It is a bloody good thing that he argues his case, from a forthrightly anti-capitalist perspective. The following formulation is more specific about his conception of truth. It accurately describes the collective nature of science and the importance critical thinking

I'm always uneasy about the concept of "speaking truth," as if we somehow know the truth and only have to enlighten others who have not risen to our elevated level. The search for truth is a cooperative, unending endeavour. We can, and should, engage in it to the extent we can and encourage others to do so as well, seeking to free ourselves from constraints imposed by coercive institutions, dogma, irrationality, excessive conformity and lack of initiative and imagination, and numerous other obstacles. ${ }^{60}$

But, in the context of his wider anarchist outlook, this argument fudges issues too, just as Said's call for open-mindedness did.

Chomsky has been reluctant to distinguish the effectiveness of different forms of political activity, invoking the importance of tactics appropriate to concrete situations: 'there has not in history ever been any answer other than, "Get to work on it." ${ }_{61}$ This neglects the question of strategy and contrasts with the strategic emphasis that Marxists place on the unique potential power of the working class to replace capitalism with socialism. There are, moreover, some activities that

55 Chomsky 1978.

56 Chomsky 1996a, pp. 60-61.

57 Chomsky 1996a, pp. 55-60.

58 Chomsky 1967, pp. 257, 285.

59 Chomsky 2003 pp. 107-108.

60 Chomsky 2007.

61 Chomsky 1996b, pp. 114-115. For an excellent appreciation of Chomsky, on this and other questions, see Arnove 1997. 
Chomsky explicitly rejects, notably involvement in revolutionary groups whose inspiration is the Marxist and Bolshevik tradition, no matter how democratic, committed to promoting socialism from below or counterposed to Stalinism they are. ${ }^{62} \mathrm{He}$ reproduces Benda's and Said's liberal hostility to Marxist organisations.

Both Said and, much more convincingly, Chomsky have drawn on Antonio Gramsci's discussion of how traditional intellectuals and organic intellectuals of the capitalist class serve ruling class interests. ${ }^{63}$ Neither has explored Gramsci's observations about organic intellectuals of the working class.

While he notes that intellectuals are privileged and generally have special skills, ${ }^{64}$ Chomsky, unlike Said and Benda, does not draw a sharp dividing line between intellectuals and mortals. Comparing specialists' interpretations with the facts of contemporary affairs, according to Chomsky the basis for understanding social issues, is

of some importance, but the task is not very difficult, and the problems that arise do not seem to me to pose much of an intellectual challenge. With a little industry and application, anyone who is willing to extricate himself from the system of shared ideology and propaganda will readily see through the modes of distortion developed by substantial segments of the intelligentsia. Everybody is capable of doing that. ${ }^{65}$

This is fine in its assessment of people's abilities but ignores the context in which they exercise them. The conception here of how critical ideas arise is voluntarist, dependent on individuals' willingness to critically assess dominant ideas. Yet Chomsky has provided convincing accounts of the operation of 'the propaganda system' in maintaining a conservative consensus, which marginalises dissident thinking in liberal capitalist societies. ${ }^{66}$ His own efforts to provide a 'course in intellectual self-defence ${ }^{67}$ are very valuable, but compared with the power of this system and the coercive forces that stand behind it, the scale of his individual contribution is necessary small. For, more profoundly than the propaganda system, our daily experience of the market and work-the fetishism of commodities - generally reinforces ruling ideas.

There is a way to systematically magnify the ideology-dissolving effect of class struggles, which are a necessary consequence of capitalist society, into more sustained and widespread criticisms of the established order, as a basis for political action. It draws on the insight that knowledge is a collective product and Gramsci's discussion of intellectuals. But his anarchism means that it is a path that Chomsky rejects. Marxists' efforts to build both the class struggle and revolutionary organisations Chomsky dismisses with quotations from Mikhail Bakunin and thinly documented attacks on the Bolsheviks rather than references to Marx's writings or specific activities. It was, however, Bakunin whose political practice was conspiratorial and elitist as a matter of principle and who justified this in writings. ${ }^{68}$

62 Chomsky 1981, pp. 222, 239; Chomsky 1972, p. 61; Chomsky 1988, pp. 285-286; Chomsky 1986.

63 Said makes the rather odd remark that '... Gramsci's pioneering suggestions in The prison notebooks which almost for the first time saw intellectuals, and not social classes, as pivotal to the workings of modern society' Said 1994, pp. 6, 10. Chomsky 1978.

For example, Chomsky 1983.

65 Chomsky 1979 pp. 4-5; also see Chomsky 1967, p. 257.

66 See especially Herman and Chomsky 1988.

67 Chomsky 2001.

68 Chomsky 1969, p. 62; Chomsky 1986; Chomsky 1988, pp. 168, 285-286, 596. Arnove 1997 outlines the weaknesses in Chomsky's position. 


\section{Marxism and revolutionary responsibilities}

Marx and Engels identified the working class as the sole social actor which could replace capitalism with a democratic society whose logic was not profit but production to satisfy human need. On this basis, they were themselves involved in building organisations which sought to ensure that the working class developed and used its capacity to change the world.

In the Communist League, their activities amongst workers in Köln and further afield during the German revolution of 1848-1849, in the International Working Men's Association from 1864 to 1872 and in their later relations with the emerging socialist workers' parties, they promoted the growth of a layer of organised workers with an awareness of working class interests and the capacity to advance social struggles by intervening into them. That was the point of the educational activity of the Communist League. An organising perspective informed publications like the Manifesto and The new Rhineland newspaper and underlay the production of in-depth analyses, like Class struggles in France, The eighteenth Brumaire of Louis Bonaparte and The civil war in France, and even theoretical texts like Capital. All were designed to be tools that organised workers could use to make their struggles more effective.

In this spirit, the 1891 Erfurt program of the German Social Democratic Party specified that 'It is the task of the Social Democratic Party to shape the struggle of the working class into a conscious and unified one and to point out the inherent necessity of its goals'. Engels had suggested including, at this point, a reference to 'workers saturated in the conscious of their class position' . ${ }^{69}$

On the other hand Marx and Engels 'pointed to intellectual strata whose social function it was to foster suitable fantasies' in the interests of capital, as Hal Draper put it. ${ }^{70}$ When people from these strata joined workers' parties, which from being thoroughly exceptional became more common late in the $19^{\text {th }}$ century, Engels argued that they should

understand that their 'academic education' — which in any case needs a basic, critical self-review_-gives them no officer's commission with a claim to a corresponding post in the party; that in our party everyone must serve in the ranks; that posts of responsibility in the party will be won not simply by literary talent and theoretical knowledge, even if both of these are present beyond a doubt, but that in addition what is required is a thorough familiarity with the conditions of the party struggle and seasoning in its forms, tested personnel reliability and sound character, and, finally, willing enlistment in the ranks of the fighters; - in short, that they, the 'academically educated people', have far more to learn from the workers, all in all, than the latter have to learn from them. ${ }^{11}$

In other words, leaders of the party needed to be able to write, to be theoretically sophisticated and to have experience as tested partisans of the working class. The background of some leaders might be the intelligentsia but Engels clearly expected all of them to be products of the party and its involvement in class struggles.

Bakunin's views about the desirability of conspiracy, during the $1860 \mathrm{~s}$, and his support for a 'revolutionary state' are apparent in Bakunin 1973a. The dictatorship of 'invisible pilots' he favoured 'must be prepared and organized in advance, for it will not come into being by itself, neither by discussions, nor by theoretical disputations, nor by mass propaganda meetings', Bakunin 1973 pp. 180-181. On Bakunin's anti-semitism see Kelly 1982, p. 236. For discussions of the conflict between Marx and Bakunin and a critique of Bakunin see Draper 1978, pp. 564-569; and Draper 1990, pp. 130-175.

69 Social Democratic Party of Germany 1891; Engels 1891.

70 Draper 1978, p. 503. The discussion of Marx and Engels' position here draws heavily on Draper. Also see Blackledge 2007, pp. 21-41.

71 Friedrich Engels reply to the editors Sächsische Arbeiter-Zeitung 1890, cited in Draper 1978, p. 515. 
Karl Kautsky made a similar point in his 1903 article 'Franz Mehring'

What the proletariat needs is scientifically grounded self-knowledge. The science that the proletariat needs cannot be that which is officially recognised and taught. Its theoreticians have to develop themselves and they are thus all autodidacts, whether they stem from the circles of university graduates or the proletariat. The object of study is the proletariat's own praxis, its role in the production process, its role in the class struggle. Only from this praxis can theory, can the self-consciousness of the proletariat arise.

The world saving unity of science and labour is therefore not to be understood as university graduates passing on to the people knowledge which they have received in bourgeois lecture halls. It is rather each of our co-fighters who is capable and has the opportunity, whether university graduates or proletarians, participating in proletarian praxis - as combatants or at the very least by researching it - in order to draw from it new scientific knowledge that will then reciprocally influence proletarian praxis by making it more fruitful. ${ }^{72}$

Lenin agreed with this - indeed he quoted from the article in One step forward, two steps backand also with Kautsky's stress on the importance of a Marxist party rallying all those oppressed under capitalism. ${ }^{73}$ Where Kautsky was primarily concerned with the petty bourgeoisie and peasantry, Lenin had already generalised the point in What is to be done?

[T] he Social-Democrat's ideal should not be the trade union secretary, but the tribune of the people, who is able to react to every manifestation of tyranny and oppression, no matter where it appears, no matter what stratum or class of the people it affects; who is able to generalise all these manifestations and produce a single picture of police violence and capitalist exploitation; who is able to take advantage of every event, however small, in order to set forth before all his socialist convictions and his democratic demands, in order to clarify for all and everyone the world-historic significance of the struggle for the emancipation of the proletariat. ${ }^{74}$

A model party member is therefore experienced, equipped with Marxist theory and capable of applying it concretely. Not only those who hold responsible positions but all members are political leaders.

In the controversy which split the Russian Social Democratic Labour Party, at its 1903 congress, Lenin, influenced by Marx, Engels and Kautsky, regarded the role of intellectuals in the party as problematic. The Bolsheviks were concerned that, as members, intellectuals would have to overcome the individualism which is an occupational disease for them; like other members they would have to be actively involved in a party organisation and therefore be subject to its discipline.$^{75}$ Much earlier, he had affirmed that 'the task is that of promoting the organisation of the proletariat, and... therefore, the role of the "intelligentsia" is to make special leaders from among the intelligentsia unnecessary. ${ }^{76}$

Gramsci's observations about the roles of intellectuals, like those on the construction of the hegemony of the working class, did not only draw on well-established Marxist insights. He also

72 Kautsky 1903a, pp. 100-1. Part of this article is elegantly but not entirely accurately translated in Kautsky 1903 b.

73 Such a view was widely shared in the German party and international social democracy, '[T]he socialist movement does all in its power to support measures which are calculated to bring about, without injury to the working-class, an amelioration of conditions for the farmer and small business man.' Kautsky 1892, chapter 5.

Lenin 1902, chapter 3 . 
applied them in the spirit of revolutionary Marxist politics. Reformist appropriators of Gramsci as well as Said and Chomsky have not been willing to acknowledge this. ${ }^{77}$ Gramsci referred to organic intellectuals of the working class as well as those of the capitalist class. Organic intellectuals of the capitalist class are generated in the capitalist production process. It is clearly the proletariat's organic intellectuals that he is referring to in the following

The political party for some social groups is nothing other than their specific way of elaborating their own category of organic intellectuals directly in the political and philosophical field and not just in the field of productive technique. These intellectuals are formed in this way and cannot indeed be formed in any other way, given the general character and the conditions of formation, life and development of the social group. ${ }^{78}$

To a greater or lesser extent, all members of a workers' party are intellectuals because one of its basic functions is to turn them 'into qualified political intellectuals, leaders and organisers'. Furthermore, a party can assimilate traditional intellectuals who join 'with the organic intellectuals of the group [i.e. class] itself'.$^{79}$ Lenin put it this way: in the party 'all distinctions as between workers and intellectuals... must be effaced'. ${ }^{80}$

One of the key purposes of a revolutionary workers' party (and even of a socialist propaganda group or circle when no party exists) is to generate critical ideas and members who are capable of leading struggles - that is, organic intellectuals. ${ }^{81}$ Such a party can be a uniquely effective means for creating leaders like this because it integrates political education, organisation and intervention into struggles so that each informs the others. It can be an organisational accumulator that draws in new members, sustains existing activists between campaigns and movements, syntheses and theorises their experience to generate fresh analyses and tactics, and thus helps to raise the level of struggles within and against capitalism.

\section{What Henryk did}

From the late 1890 s, when he was at high school, until his death in 1950, at the age of 69 , Henryk Grossman was politically active. ${ }^{82} \mathrm{He}$ believed that it was the responsibility of socialists to create and sustain a revolutionary Marxist organisation, whenever possible. In his twenties, he was involved in building a socialist group from the ground up.

By 1900, social democratic organisation amongst Jewish workers in Galicia, the Austrian occupied province of partitioned Poland, had fallen apart. Associations of Yiddish speaking workers, affiliated to the Galician Social Democratic Party (GPSD), had existed in a number of cities in the

77 See Harman 1983 and Anderson 1976.

78 The previous discussion outlines how 'The capitalist entrepreneur creates alongside himself the industrial technician, the specialist in political economy, the organisers of a new culture, of a new legal system, etc.' i.e. clearly not through political parties, Gramsci 1999, pp. 135, 149-150.

79 Gramsci 1999, 150-151.

80 Lenin 1902, chapter 4C. Alasdair MacIntyre (2008a, p. 100) made the same point:

If Marx had approached the working-class movement from the outside as a middle-class
sociologist, he would never have had working-class experience made available to him in the way
in which it was. Mere speculative curiosity leads nowhere. The only intellectual who can hope to
aid the working class by theoretical work is one who is willing to live in the working-class
movement and learn from it, revising his conceptions all the time in the light of his and its
experience.'

81 For the lineage of the general case for a revolutionary socialist party and a more systematic exposition, see Harman 1968-1869 and Molyneux 2003. Tony Cliff's multi-volume Lenin 1975-1979, explores Lenin's contributions in their original context. Also see Lukács 1977. On propaganda groups see Armstrong 2007.

82 For further details about Grossman's activities and references see Kuhn 2007. 
mid 1890s. But towards the end of the century they had collapsed in most places and continued only as a rump in the province's capital Lemberg/Lwow/L'viv. A recession, a political crack-down by the authorities and the indifference of the GPSD leadership were the main reasons.

Early in the $20^{\text {th }}$ century Grossman, a student from a bourgeois family, started to build a Marxist association of Jewish workers in Kraków, the cultural capital of Poland and the seat of the administration of western Galicia. To begin with, according to the notes of his friend the Australian novelist Christina Stead, he hung out in cafés where political workers gathered. Many of them had Zionist sympathies. Labour Zionism was expanding rapidly at this point and was the main competitor to social democracy for the support of Yiddish speaking workers.

Twelve people founded Postęp (Progress in Polish) as a general association of Jewish workers on 20 December 1902. Grossman was its secretary. The association had early success amongst Jewish bakers. Postęp's members led industrial struggles and formed branches of the central Austrian social democratic trade unions for newly organised groups of workers. They arranged lectures on unionism, politics, literature, and science, and conducted literacy classes. The Kraków association was in touch with similar organisations, in Lemberg and other towns, that were likewise at once trade union, political and cultural bodies. They grew rapidly as the economy boomed in 1904 and then under the influence of the 1905 revolution across the border in the Russian empire. By 1905 Grossman had "recruited at least half of the membership of the Jewish proletarian organization" in Kraków, made up of several hundred workers and a few students.

The Jewish associations and union branches were initially affiliated to the Social Democratic Party. Particularly after it off-loaded responsibility for organising Ukrainian workers in 1899 and became the Polish Social Democratic Party of Galicia (PPSD), the Party was increasingly nationalist and suspicious of its own Yiddish-speaking affiliates. To overcome this obstacle to building Marxist influence in the Jewish working class, Jewish social democratic groups across Galicia left the PPSD to form the Jewish Social Democratic Party of Galicia (JSDP) on May Day 1905. Grossman was its founding secretary.

As the new Party's theorist, Grossman generalised his own and the JSDP's experience in a pamphlet on Bundism in Galicia.

Party consciousness is the multi-faceted expression of the proletariat's class interests and the most far-reaching interpretation of conclusions drawn from the objective trends of real social development. Workers' parties do not always fulfil this requirement (as evidenced by the PPSD). Both the character and the content of collective party thought remain directly dependent on the particular party's adjustment to the very working class whose expression it should be.

... The closest possible adaptation of the party organization to the historical forms of the Jewish proletariat's condition... could only be achieved through the mutual organic growth of the party organization and the workers' movement itself, just as the latter has grown out of capitalist society. ${ }^{83}$

His assessment, like Lenin's theory of the party, drew on the orthodoxy of Second International Marxism, systematically expressed by Kautsky. ${ }^{84}$

83 Grossman 1907, pp. 42-43.

84 See Lih 2006. More generally, Shandro 1997/1998 and Blackledge 2006 have noted that the enduring value of Kautsky's contributions to Marxism have been understated in many recent treatments. But Lenin long before pointed out that 'We know from many of Kautsky's works that he knew how to be a Marxist historian, and that such works of his will remain a permanent possession of the proletariat in spite of his subsequent apostasy', Lenin 1918. 
There is one specific story about Grossman's agitational activities in Galicia that must be included in a Deutscher Lecture.

Chrzanów, about $45 \mathrm{~km}$ from Kraków was dominated by the town's Jewish bosses. Half of the population of around 6,000 was Jewish, many of them Khassids, members of fanatical Jewish sects. One of the main industries was printing. Many workers laboured for fifteen hours a day, six days a week. Their bosses controlled local political life, through the municipal council, and religious life, through the kehile (the local religious administration). Paragons of the community like these did not appreciate outsiders whose social democratic agitation disrupted the established order. In early June 1906 they expelled two JSDP members from the town. Soon Henryk Grossman came to give heart to the local comrades. Amongst the traditionally clothed inhabitants, he was easy to identify: a welldressed, middle class, young gentleman. Incited by Khassidic zealots a large mob roughed him up and trashed the rooms of the recently established JSDP affiliate.

Afterwards, the JSDP produced a leaflet that countered the arguments of the Chrzanów worthies that Jewish socialists wanted to organise pogroms, as in Russia. In fact 'who took the Jew's side in Russia and who defended them, if not the socialists?' The local bosses were the ones who had instigated a pogrom, against the socialists. Grossman also took legal action over the assault. $\mathrm{He}$ won, demonstrating that the parochial despots were not all powerful and turning the affair into a publicity coup for the JSDP. Christina Stead's short story 'The Azhdnov tailors' is based on this incident. ${ }^{85}$

Isaac Deutscher was born in Chrzanów to a family which ran a printing firm in 1907. His father was a Khassid.

Although he moved to Vienna at the end of 1908, Grossman's close association with the JSDP continued until at least 1910. For the period immediately before and during World War I, no evidence has come to light of political involvement, although his publications during the period give hints of his continuing Marxist views. The German-Austrian Social Democratic Party had opposed the existence of the JSDP from the start. So joining it was not an attractive proposition.

In 1919 or 1920, when Grossman joined the Communist Workers Party of Poland (KPRP), if not before, he adopted a package of Leninist politics, which included elements of his earlier political outlook, notably his belief that socialists should be involved in building revolutionary organisations. Grossman was, between 1922 and 1925, the secretary and then the chairperson of the People's University (PU) in Warsaw. This educational institution was one of the Party's most important fronts, as the KPRP was a semi-clandestine organisation. The PU organised about forty lectures a month, each attended by fifty to three hundred people, and programs of talks for trade unions. It supported a publishing program and managed several buildings, including a cinema. Through PU activities, Communists involved in different areas, unionists, students, activists in campaigns could come together legally.

In 1925, after a series of arrests and periods in prison, the Polish authorities forced Grossman into a qualified exile. He took up a post at the Marxist Institute for Social Research in Frankfurt am Main and was now doubly insulated from conservatising pressures. On the one hand, his well-paid post at the Institute meant that he was not financially dependent on either a more conventional, bourgeois institution or a political organisation with a line. While he lived in Germany he remained a supporter of the Communist International and Lenin's theory of the party. He was politically engaged, a close fellow-traveller of the Communist Party of Germany (KPD) and an admirer of the Soviet Union. In 1932, he returned from a study tour of the USSR starry-eyed. Yet, in order to avoid provoking the German and Polish authorities, he did not join the KPD. So he was not, on the other hand, subject to the Party's discipline as it imposed the new Stalinist orthodoxies. We have 
seen that Grossman defended Marx's analysis of the anatomy of capitalism against the distortions that became the Stalinist line in economics.

Grossman's work in economic theory, from 1919 to his death, embodied commitment to working class self-emancipation, recognition that socialists need to organise politically for that goal and insights opened up by the success of the Bolshevik revolution. The subordination of Communist Parties to the interests of the rising Russian bureaucracy created a contradiction between the fundamentals of Marxist politics and his loyalty to the Comintern and the Soviet Union. Consequently, professional and amateur mouthpieces of Stalinism distorted and denounced Grossman's best-known work. For a period, he resolved the contradiction by re-establishing a consistency between his own political perspectives and the classical Marxism that was the basis for his theoretical insights. ${ }^{86}$

The disaster of the Nazi's victory in 1933 and Grossman's accurate assessment that the tactics of the KPD, the Comintern and the Russian leadership had failed to build an effective opposition to the Nazi's rise to power led him to explore dissident Communist analyses of what had gone wrong. He recommended Trotsky's 'The German catastrophe' to Paul Mattick. This was not, however, a decisively 'Trotskyist moment' as Grossman was apparently closer to the Socialist Workers Party of Germany (SAP). For a period in 1934 and 1935, there were meetings, which discussed revolutionary politics and included the SAP leaders Paul Frölich and Jakob Walcher at Grossman's place in Paris.

There was a sharp contrast between Grossman's attitude to politics and that of Max Horkheimer, who had become the Institute's director during the early 1930s. Grossman appreciated Horkheimer's work on philosophy. But they were published in German in the Institute's rather inaccessible journal, even after it had gone into exile, first in Geneva, then New York. Grossman suggested in 1937 that the essays be published as a book, for a wider audience. As in the natural so in the social sciences 'Really, from an activist standpoint, you should be interested in confronting broad layers of young people. One should never forget that the victory of Cartesianism was not simply achieved through the power of pure thought but was supported in the university by the fists and clubs of Dutch students, who answered the brutal force of scholasticism with the similar force of their fists! ${ }^{87}$

Apparently influenced by Russian support for Republican Spain during the civil war, Grossman around 1937 sadly again became a fellow-traveller of the Soviet Union and an uncritical supporter of Stalin's foreign policy. He continued to engage in political activities that he mistakenly believed expressed the perspective that informed his research. In 1938, he moved to New York and, during and after the War, was involved in groups associated with the KPD.

On May Day 1949, a few months after arriving in eastern Germany to take up a professorial chair in political economy at the University of Leipzig, he signed up for the Society for German-Soviet Friendship. On June 9 he became a member of the Socialist Unity Party (SED) which ruled Communist East Germany, under the supervision of Stalin's regime in Russia. ${ }^{88}$ Nevertheless Grossman still adhered not only to the Marxist perspective that it is a responsibility of socialists to

86 Letter from Henryk Grossman to Paul Mattick, March 6, 1933, Mattick Collection, Internationaal Instituut voor Sociale Geschiedenis.

87 Letter from Grossman to Horkheimer, August 1, 1937, Horkheimer 1995b, p. 204; also see letter from Grossman to Horkheimer, January 30, 1935, Horkheimer 1995a, pp. 311-12.

88 File note, March 15, 1949, VdN-Akte von Henryk Großmann 13630, Bezirksrat Leipzig, 20237, Sächsische Staatsarchiv Leipzig; Ergänzungsblatt zum Personalfragebogen, July 4, 1950, ,Henryk Grossmann’ PA 40, Universitätsarchiv Leipzig (UAL), p. 88; Persönlicher Fragebogen eines Wissenschaftlers, August 3, 1949, UAL, p. 70 . 
be politically active but also to his own contributions to Marxist theory, even when these contradicted Stalinist orthodoxies.

Already ill for months, he died on 24 November 1950. So he was not affected by the SED campaign from 1949 that finally subordinated all institutions, notably the unions and universities, to the Stalinist state. The regime targeted, in particular, Party members who had been in western exile during the Nazi dictatorship.

With the benefit of hindsight but also from the perspective of some of his Marxist contemporaries, we can recognise weaknesses and contradictions in Grossman's choices and actions. In practice, the Stalinist organisations in which he placed his faith undermined rather than advanced workers' interests. There is, nevertheless, much to identify with in his Marxism and his political career.

In 1946 Henryk Grossman explained his revolutionary sentiment to Christina Stead: 'I feel as if I saw a dangerous badly made deadly machine running down the street, when it gets to that corner it is going to explode and kill everyone and I must stop it: once you feel this it gives you great strength, you have no idea there is no limit to the strength it gives you. ${ }^{89} \mathrm{We}$ can draw strength from Grossman's systematic account of the contradictions at the heart of capitalist production and some important features of his political and organisational commitments in our own efforts to realise the project of working class self-emancipation.

\section{References}

Ahmad, Aijaz 1994 'Orientalism and after: ambivalence and metropolitan location in the work of Edward Said' in Aijaz Ahmad In theory: classes, nations, literatures, London, Verso: 159-220.

American Friends Service Committee 1955, Speak truth to power: a Quaker search for an alternative to violence, Philadelphia.

Anderson, Perry 1976, 'The antinomies of Antonio Gramsci', New left review, 100: 5-78.

Armstrong, Mick 2007, From little things big things grow: strategies for building revolutionary socialist organisations, Melbourne, Socialist Alternative.

Arnove, Anthony 1997, 'In perspective: Noam Chomsky', International socialism, 74: 117-140.

Associated Press '2008, Brown wants new global financial order', International herald tribune, 26 September, accessed 7 December 2008.

Bakunin, Mikhail 1973a, 'The Program of the International Brotherhood', Bakunin on Anarchy, George Allen \& Unwin London: 148-153.

Bakunin, Mikhail 1973b letter to Albert Richard, August 1870 Bakunin on anarchy, London, George Allen \& Unwin: 177-182.

Bank for International Settlements 2005, Triennial central bank survey of foreign exchange and derivatives market activity, www.bis.org/publ/rpfx05t.pdf, accessed 16 May 2008.

Barbon, Alex (Jean Van Heijenoort) 1946, 'La dialectique du capital' Revue internationale 2, 8: 124-136.

Bauer, Otto 1986, 'The accumulation of capital' History of political economy 18, 1: 88-110 [1913].

Behrens, Fritz 1952, Die Marxsche politische Ökonomie, Berlin, Akademie Verlag.

Behrens, Fritz 1976, Zur Methode der politischen Ökonomie, Berlin, Akademie Verlag 1952: 45-48.

Benda, Julien 1959, The betrayal of the intellectuals, Boston, Beacon [1927].

Benjamin, Walter 1989, “Theses on the philosophy of history," in Stephen Bronner and Douglas Kellner, Critical theory and society, New York, Routledge: 260-61 [duplicated 1942, written 1940].

89 Letter from Stead to Blake, September 12, 1946, Stead and Blake 2005, p. 355, ellipsis in the original. Grossman's concrete simile recalled György Lukács's more elevated account of the revolutionary role of the working class, that also emphasised the significance of capitalist crises in the revolutionary process, Lukács 1971, p. 70. Also see Benjamin 1989. 
Bible, King James version, http://etext.lib.virginia.edu/etcbin/toccer-

new2? id=KjvJohn.sgm\&images=images/modeng\&data=/texts/english/modeng/parsed\&tag=public\&part=8\&divis ion=div1, accessed 8 December 2008, John 8.18 and 8.32.

Blackledge, Paul 2006, ‘Karl Kautsky and Marxist historiography’ Science \& society 70, 3: 337-359.

Blackledge, Paul 2007, 'Marx and intellectuals' in David Bates (ed.) Marxism, intellectuals and politics, Houndmills, Palgrave Macmillan: 21-41.

Blackledge, Paul 2008, 'Marxism and ethics', International socialism 120: 125-150.

Bond, Patrick 1998, Uneven Zimbabwe, Trenton, Africa World Press.

Bukharin, Nikolai 1972, Imperialism and the accumulation of capital in Rosa Luxemburg and Nikolai Bukharin Imperialism and the accumulation of capital, London, Allen Lane [1925].

Bukharin, Nikolai 1973, Imperialism and world economy, New York, Monthly Review Press [written 1915, published 1917].

Calavita, Kitty 2002, 'Engaged research, "goose bumps”, and the role of the public intellectual, Law and Society Association presidential address', Law and society review 36, 1: 5-20.

Chomsky, Noam 1967, 'The responsibility of intellectuals', www.chomsky.info/articles/19670223.htm, accessed 4 May 2008.

Chomsky, Noam 1969, 'Objectivity and liberal scholarship,' American power and the new mandarins, Chatto \& Windus, London: 23-129.

Chomsky, Noam 1972, Problems of knowledge and freedom: the Russell Lectures, London, Barrie \& Jenkins.

Chomsky, Noam 1978, Intellectuals and the state, www.ditext.com/chomsky/is.html, accessed 3 May 2008.

Chomsky, Noam 1979, Language and responsibility, Hassocks, Harvester Press.

Chomsky, Noam 1981, 'Some tasks for the left' Radical priorities, Black Rose, Montreal: 219-231 [1969].

Chomsky, Noam 1983, 'The reasons for my concern' Response to Celia Jakubowicz, letter 13 June, www.chomsky.info/letters/19830613.htm, accessed 3 May 2008.

Chomsky, Noam 1986, 'The Soviet Union versus socialism', www.chomsky.info/articles/1986----.htm, accessed 3 May 2008.

Chomsky, Noam 1988, 'An American view of the ideological confrontation of our time' interview, Language and politics Black Rose, Montréal: 284-296 [1980].

Chomsky, Noam 1996a, 'Writers and intellectual responsibility' in Power and prospects: reflections on human nature and the social order, South End, Boston: 55-69.

Chomsky, Noam 1996b, Class warfare: interviews with David Barsamian, Monroe, Common Courage Press.

Chomsky, Noam 2001 'Intellectuals and the responsibilities of public life' interview, www.chomsky.info/interviews/20010527.htm, accessed 16 May 2008.

Chomsky, Noam 2003, Power and terror: post-9/11 talks and interviews, Seven Stories Press, New York.

Chomsky, Noam 2007, 'On responsibility, war guilt and intellectuals' interviewed by Gabriel Matthew Schivone, www.chomsky.info/interviews/20070803.htm, accessed 16 May 2008.

Cliff, Tony 1975-1979, Lenin four volumes, Bookmarks, London.

Dabrowski, Hartmut 2006, personal communication, 26 January.

Davidson, Sinclair 2008, “"Sub-prime” should not be the basis for increasing financial regulation' IPA review, March: 15.

Day, Richard 1981, The “crisis” and the “crash”: Soviet studies of the west (1917-1939), NLB, London.

Deutschmann, Christoph 1973, Der linke Keynesianismus Athenäum, Frankfurt am Main.

Draper, Hal 1978, Karl Marx's theory of revolution volume 2: the politics of social classes, Monthly Review Press, New York.

Draper, Hal 1990, Karl Marx’s theory of revolution volume 4: critique of other socialisms, Monthly Review Press, New York. 
The economist 2006, 'Capitals of capital—hedge funds', 2 September.

The economist 2008, 'The financial crisis: what next?', 18 September.

Engels, Friedrich 1891, 'Zur Kritik des sozialdemokratischen Programmentwurfs 1891', www.mlwerke.de/me/me22/me22_225.htm, accessed 1 July 2008.

Finthammer, Volker, Georg Fülberth, Sabine Reiner and Jürgen Scheele 1989, 'Widerkehr des “legalen Marxismus”?' Perspektiven, 5, June: 5-16.

Franklin, Matthew 2008, 'PM Kevin Rudd unlocks \$20bn future fund', The Australian, 3 October, http://www.theaustralian.news.com.au/story/0,25197,24439161-643,00.html, accessed 8 October 2008.

Freeman, Alan 1996, ‘The psychopathology of Walrasian Marxism’ in Alan Freeman and Guglielmo Carchedi (eds) Marx and non-equilibrium economics Elgar, Cheltenham: 1-27.

Freeman, Alan 2008, 'The discontents of Marxism’ Debatte, 16, 1: 122-131.

Gramsci, Antonio 1995, Further selections from the prison notebooks, Lawrence \& Wishart, London.

Gramsci, Antonio 1999, Selections from the prison notebooks, ElecBook, London [based on Lawrence and Wishart edition, London 1971].

Gramsci, Antonio 2008, Il materialismo storico e la filosofia di Benedetto Croce, www.liberliber.it/biblioteca/g/gramsci/il_materialismo_storico_e_la_filosofia_etc/pdf/il_mat_p.pdf, accessed 27 September 2008.

Grossman, Henryk 1907, Bundizm in Galitsien, Publishing House of the Social democrat (Kraków, 1907 [cover has 1908, title page 1907, serialized in Sotsial-demokrat between September 13 and November 29, 1907].

Grossman, Henryk 2000, 'The theory of economic crises', in Paul Zarembka and Susanne Soederberg (eds) Value, capitalist dynamics and money, Research in political economy, 18, New York, Elsevier Science: 171-80 [1922].

Grossmann, Henryk 1928, 'Eine neue Theorie über Imperialismus und die soziale Revolution', Archiv für die Geschichte des Sozialismus und der Arbeiterbewegung, 13: 161-62 [also www.marxists.org/deutsch/archiv/grossmann/1928/xx/anti-sternberg.htm].

Grossmann, Henryk 1929, 'Die Änderung des ursprunglichen Aufbauplans des Marxschen "Kapital” und ihre Ursachen', Archiv für die Geschichte des Sozialismus und der Arbeiterbewegung, 14: 305-338 [A section of the article is translated into English in Kenneth Lapides, 1992 'Henryk Grossmann and the debate on the theoretical status of Marx's Capital' Science \& society 56, 2: 144-150].

Grossmann, Henryk 1970, Das Akkumulations- und Zusammenbruchsgetz des kapitalistischen Systems (zugleich eine Krisentheorie), Frankfurt am Main, Verlag Neue Kritik [1929].

Grossmann, Henryk 1977, 'Marx, classical political economy and the problem of dynamics', Capital and class, 2 and 3 : 32-55 and 67-99 [1941].

Grossmann, Henryk 1992 The law of accumulation, London, Pluto Press [1929 also www.marxists.org/archive/grossman/1929/breakdown/index.htm].

Harman, Chris 1968-1869 Party and class www.marxists.de/party/harman/partyclass.htm, accessed 23 September 2007.

Harman, Chris 1983, Gramsci versus reformism, London Socialist Workers Party.

Harman, Chris 2007, 'The rate of profit and the world today', International socialism, 115: 141-161.

Harman, Chris 2008, 'From the credit crunch to the spectre of global crisis' International socialism, 118: $27-42$.

Heinrich, Michael 2006, Die Wissenschaft von Wert, Münster, Westfälisches Dampfboot.

Herman, Edward S. and Noam Chomsky 1988, Manufacturing consent: the political economy of the mass media, New York, Pantheon.

Hilferding, Rudolf 1981. Finance capital: a study of the latest phase of capitalist development, London, Routledge \& Kegan Paul [1910].

Hilferding, Rudolf 1982, 'Die Aufgaben der Sozialdemokratie in der Republik,' Zwischen den Stühlen oder über die Unvereinbarkeit von Theorie und Praxis: Schriften Rudolf Hilferdings 1904 bis 1940, Bonn, J. H.W. Dietz [1927].

Horkheimer, Max 1995a, Gesammelte Schiften Band 15: Briefwechsel 1913-1936, Frankfurt am Main Fischer.

Horkheimer, Max 1995b, Gesammelte Schiften Band 16: Briefwechsel 1937-1940, Frankfurt am Main Fischer. 
Howard, Michael Charles and John Edward King 1989, A history of Marxian economics, volume 1 1883-1929, Princeton, Princeton University Press.

Howard, Michael Charles and John Edward King 1992, A history of Marxian economics, volume 2, 1929-1990, London Macmillan.

International Monetary Fund 2007, Global financial stability report 2007, 2007, Statistical appendix tables 3 and 4, available at www.imf.org/external/pubs/ft/gfsr/2007/01, accessed 16 May 2008.

Kautsky, Karl 1892, The class struggle (Erfurt Program), chapter 5, http://www.marxists.org/archive/kautsky/1892/erfurt/index.htm, accessed 2 July 2008

Kautsky, Karl 1902, ‘Krisentheorien’ Neue Zeit, 20, 2: 37-47, 76-81, 110-118.

Kautsky, Karl 1903a, 'Franz Mehring' Neue Zeit, 22, 4: 97-108.

Kautsky, Karl 1903b, 'The intellectuals and the workers', www.marxists.anu.edu.au/archive/kautsky/1903/xx/intwork.htm, accessed 1 July 2008, accessed 16 May 2008.

Kautsky, Karl 1907, Socialism and colonial policy, www.marxists.org/archive/kautsky/1907/colonial/index.htm.

Kelly, Aileen 1982, Michael Bakunin: a study in the psychology and politics of utopianism, Clarendon, Oxford.

Kliman, Andrew 2007, Reclaiming Marx’s 'Capital': a refutation of the myth of inconsistency, Lantham, Lexington.

Körner, Klaus 1996, 'Die Europäischen Verlagsanstalt 1945-1979' in Sabine Groenewold (ed.) Mit Lizenz: Geschichte der Europäischen Verlagsanstalt 1946-1996, Hamburg, eva: 35-134.

Krause, Werner and Günther Rudolph1980, Grundlinien des ökonomischen Denkens in Deutschland 1848 bis 1945 , Berlin, Akademie-Verlag.

Krugman, Paul 2008, 'Partying like it's 1929' New York times, 21 March www.nytimes.com/2008/03/21/opinion/21krugman.html, accessed 7 December 2008.

Kuhn, Rick 2004, 'Economic crisis and socialist revolution: Henryk Grossman's Law of accumulation, its first critics and his responses', in Paul Zarembka (ed.) Neoliberalism in crisis, accumulation, and Rosa Luxemburg's legacy, Research in political economy, 21, Elsevir, Amsterdam: 181-22 [preprint http://dspace.anu.edu.au/handle/1885/40145].

Kuhn, Rick 2007, Henryk Grossman and the recovery of Marxism, Chicago, University of Illinois University Press.

Lenin, Vladimir Ilyich 1894 What the 'friends of the people' are and how they fight the social-democrats, marxists.org/archive/lenin/works/1894/friends/08.htm, accessed 16 September 2008.

Lenin, Vladimir Ilyich 1902, What is to be done?, chapter 3 www.marxists.org/archive/lenin/works/1901/witbd/iii.htm, accessed 2 July.

Lenin, Vladimir Ilyich 1904, One step forward, two steps back, chapter 1, http://www.marxists.org/archive/lenin/works/1904/onestep/i.htm, accessed 2 July 2008.

Lenin, Vladimir Ilyich 1918, 'The proletarian revolution and the renegade Kautsky', www.marxists.org/archive/lenin/works/1918/prrk/soviet_republic.htm, accessed 6 October 2008.

Lenin, Vladimir Ilych 1977, Imperialism: The Highest Stage of capitalism, Selected works volume 1, Moscow Progress Publishers [1916].

Lih, Lars T. 2006, Lenin rediscovered: What is to be done? in context, Leiden, Brill.

Lukács, Georg 1971, History and class consciousness, Merlin, London: [1923].

Lukács, Georg 1977, Lenin: a study in the unity of his thought, London, New Left Books.

Luxemburg, Rosa 1963, The accumulation of capital, London, Routledge: 366-367 [1913].

Luxemburg, Rosa 1972, The accumulation of capital-an anti-critique: the accumulation of capital, or what the epigones have made of Marx's theory, in Rosa Luxemburg and Nikolai Bukharin Imperialism and the accumulation of capital, London, Allen Lane [1915].

MacIntyre, Alasdair 2008a, 'What is Marxist theory for' Alasdair MacIntyre’s engagement with Marxism: selected writings 1953-1974, Brill, Leiden: 95-103 [1959].

MacIntyre, Alasdair 2008b, 'Freedom and revolution', in Alasdair MacIntyre's engagement with Marxism: selected writings 1953-1974, Brill, Leiden: 123-134 [1960]. 
Mandel, Michael 2008, 'Why the Paulson Plan is DOA', BusinessWeek, 30 March, www.businessweek.com/the_thread/economicsunbound/archives/2008/03/why_the_paulson.html, accessed 11 October 2008.

Marx, Karl and Frederick Engels 1970, Manifesto of the Communist Party, Moscow, Progress Publishers [1848].

Molyneux, John 2003, Marxism and the party, Chicago, Haymarket [1978].

New York times 2004 'Excerpts from speeches on broad variety of issues at the convention in Boston', 28 July: 8.

Rollins, Adrian 2008, 'RBA slashes rates on recession fears', Australian financial review, 8 October: 1.

Said, Edward 1994, Representations of the intellectual: the 1993 Reith lectures, Pantheon, New York.

Scheele, Jürgen 1999, Zwischen Zusammenbruchsprognose und Positivismusverdikt: Studien zur politischen und intellektuellen Biographie Henryk Grossmanns (1881-1950), Lang, Frankfurt am Main.

Schmiede, Rudi 1973, Grundprobleme der Marx’schen Akkumulations- und Krisentheorie, Frankfurt am Main Athenäum.

Shandro, Alan 1997/1998, 'Karl Kautsky: on the relation of theory and practice', Science \& society, 61, 4: $474-501$.

Shoul, Bernice '1965, Similarities in the work of John Stuart Mill and Karl Marx', Science \& society, 29, 3: $270-295$.

Shoul, Bernice 1947, 'The Marxian theory of capitalist breakdown', PhD thesis, Radcliffe College, www.marxists.org/archive/shoul/1947/breakdown/index.htm1, accessed 8 December 2008.

Shoul, Bernice 1957, ‘Karl Marx and Say’s Law’, Quarterly journal of economics, 71, 4: 611-629.

Shoul, Bernice 1967, 'Karl Marx’s solutions to some theoretical problems of classical economics', Science \& Society, 31, 4: 449-460.

Skapinker, Michael 2008, 'Why fallen titans are more hated in America', Financial times (Asian edition), 7 October: 11.

Social Democratic Party of Germany 1891, The Erfurt Program, www.marxists.org/history/international/socialdemocracy/1891/erfurt-program.htm, accessed 16 May 2008.

Stead, Christina 1986, 'The Azhdanov tailors', in Christina Stead (ed.) The ocean of story, Ringwood, Penguin: 115$125[1971]$

Stead, Christina 2005, letter to Blake, September 12, 1946, Christina Stead and William J. Blake Dearest Munx: the letters of Christina Stead and William J. Blake, Carlton, Miegunyah Press.

ten Brink, Tobias and Thomas Walter 2001, 'Wie stabil ist der heutige Kapitalismus?' Sozialismus von Unten, 6 , www.sozialismus-von-unten.de/archiv/svu6/krise-kapital.html, accessed 10 October 2008.

Verlag Neue Kritik n. d., 'Verlagsgeschichte' http://cf.webdata.de/web22/NeueKritik/inc/Verlagsgeschichte.cfm, accessed 6 October 2008.

White, Jeffrey 2008, 'On crisis, Europe to US: "I told you so"', Christian Science monitor, 10 October: 7.

World Trade Organization 2005, International trade statistics 2005, www.imf.org/external/pubs/ft/gfsr/2007/01/chi/0407c.pdf, accessed 16 May 2008.

World Trade Organization 2006 International trade statistics 2006, www.wto.org/english/res_e/statis_e/its2006_e/its2006_e.pdf, accessed 8 December 2008.

Yaffe, David 1973, 'The Marxian theory of crisis, capital and the state', Economy and society, 2: 186-232. 